Sari Pediatri, Vol. 7, No. 1, Juni 2005: 34-38

\title{
Peran Eritropoietin pada Anemia Akibat Keganasan pada Anak
}

\author{
Reni Suryanty, Nelly Rosdiana, Bidasari Lubis
}

\begin{abstract}
Anemi relatif sering terjadi pada kasus keganasan hematologi atau tumor padat, namun penyebab anemia belum jelas diketahui. Eritropoietin merupakan suatu glikoprotein hormon yang dapat merangsang proliferasi dan diferensiasi sel-sel progenitor darah merah. Salah satu penanganan anemia yaitu pemberian transfusi yang mempunyai banyak risiko diantaranya risiko transmisi infeksi, hemolitik, non- hemolitik, penumpukan besi dan penekanan produksi eritropoietin endogen. Dipertimbangkan pemberian eritropoietin eksogen (human recombinan erythropoietin) yang identik dengan eritropoietin endogen pada keganasan terutama yang mendapat kemoterapi bila $\mathrm{Hb} \mathfrak{£} 10 \mathrm{~g} / \mathrm{dL}$ dengan dosis $150 \mathrm{U} / \mathrm{kg}$ BB 3x seminggu selama 4 minggu dan dosis dapat ditingkatkan hingga 300 U/kg BB dan diberikan selama 4 - 8 minggu. Diperlukan pemeriksaan secara periodik terhadap kadar besi, TIBC, (total iron binding capacity) saturasi transferin dan feritin. Rhu-EPO dipasaran yaitu epoetin alfa dan beta. Efek samping Rhu-EPO antara lain hipertensi, nyeri kepala, nyeri tulang, mual, edem, lemah dan diare. Dilaporkan pada epoetin beta relatif jarang terjadi hipertensi dan dilaporkan tentang terjadinya kasus pure red cell aplasia pada pemberian epoetin alfa (eprex).
\end{abstract}

Kata kunci : keganasan, anemia, eritropoietin

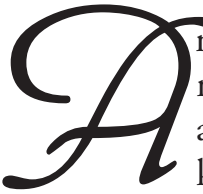

nemia adalah berkurangnya sel darah merah atau konsentrasi hemoglobin akibat gangguan keseimbangan antara kehilangan sel darah merah dan gangguan produksi. ${ }^{1}$ Anemia relatif lebih sering terjadi pada pasien dengan keganasan hematologi atau tumor padat. Penyebab anemia pada keganasan masih belum jelas diketahui, tetapi pada kebanyakan kasus dapat disebabkan akibat pengobatan, latar belakang penyakit

\footnotetext{
Alamat korespondensi:

Dr. Nelly Rosdiana, SpA.

Bagian Ilmu Kesehatan Anak FK USU/RS HAM Jalan Bunga Lau No. 17 Medan.

Telepon: (061) 8361721, Fax: (061) 8361721.

dr. Reni Suryantii PPDS IKA FK - USU / RSHAM, Bagian Ilmu Kesehatan Anak, Medan
}

ataupun keduanya yang berpengaruh terhadap respon produksi eritropoietin. $^{1-3}$

Untuk mengatasi anemia dan mengurangi kebutuhan transfusi yang berulang pada kasus keganasan maka Brumariu dkk ${ }^{4}$, Ludwig $\mathrm{dkk}^{5}$, mempertimbangkan penggunaan pemberian eritropoietin eksogen (recombinant human erythropoetin $=\mathrm{rhu}-\mathrm{EPO}$ ) karena pemberian transfusi darah mempunyai risiko transmisi infeksi (transfussion transmitted disease) dan dapat menyebabkan risiko hemolitik, non hemolitik, penumpukan besi, imunosupresi, serta menekan produksi eritropoietin endogen. ${ }^{4,5}$

Recombinan human erythropoetin (rhu-EPO) mengandung protein kecil yang tersusun dari 165 amino acid glycoprotein yang merupakan hasil rekayasa genetik (recombinant DNA technology) yang indentik eritropoietin endogen, ${ }^{1,4}$ merupakan asam amino dan mempunyai dampak merangsang maturasi retikulosit 
menjadi eritrosit pada sel induk di sumsum tulang, meningkatkan jumlah eritrosit dan selanjutnya meningkatkan cadangan oksigen serta memperbaiki kemampuan penyebaran oksigen. ${ }^{1}$

\section{Eritropoiesis}

Eritropoiesis merupakan proses pembentukan sel darah merah. Sel darah merah berfungsi sebagai pengangkut oksigen ke jaringan dan mengikat $\mathrm{CO}_{2}$ dari jaringan. Dalam keadaan normal eritropoiesis memerlukan 3 faktor yaitu (1) stem sel hematopoetik, (2) sitokin spesifik, growth factor dan hormonal regulator, serta (3) hematopoietik yang mempengaruhi microenvirontment yang merupakan stroma pendukung dan interaksi sel dengan sel yang diikuti proliferasi dan diferensiasi hematopoetik sel stem dan mempengaruhi erythroid progenitor yang akhirnya menghasilkan sel darah merah yang matur.

Proliferasi dan maturasi ini diatur oleh sitokin termasuk eritropoietin sebagai faktor yang terpenting dalam mekanisme ini. Bila terjadi hipoksia, nefron ginjal akan merespons dengan memproduksi eritropoietin. Eritropoietin (EPO) merupakan suatu glikoprotein hormon dengan berat molekul $30-39 \mathrm{kD}$ yang akan terikat pada reseptor spesifik progenitor sel darah merah yang selanjutnya memberi sinyal merangsang proliferasi dan diferensiasi. ${ }^{6}$ Sebaliknya bila terjadi peningkatan volume sel darah merah di atas normal misalnya oleh karena transfusi, aktivitas eritropoietin di sumsum tulang akan berkurang. ${ }^{1,2,7}$

Eritropoietin terutama dihasilkan oleh peritubular interstitial (endothelial) ginjal $( \pm 90 \%)$ dan sisanya (10$15 \%)$ dihasilkan di hati. ${ }^{1,2,4,7,8}$ Produksi EPO akan meningkat pada keadaan anemiaa ataupun hipoksia jaringan. $^{7-9}$

\section{Patofisiologi Anemia Keganasan}

Anemia merupakan kelainan hematologi yang paling sering ditemukan pada pasien keganasan anak dan mempunyai pengaruh yang signifikan terhadap klinis dan kualitas hidup pasien. Faktor-faktor seperti tipe, stadium, jenis keganasan dan intensitas kemoterapi atau radiasi serta komplikasi pengobatan seperti infeksi, sepsis mendukung terjadinya anemiaa ini. Beberapa mekanisme yang dapat menjelaskan terjadinya anemiaa pada keganasan.

- Kerusakan sumsum tulang karena pengaruh langsung keganasan itu sendiri (bone marrow replacement).7,10,11

- Kemoterapi dapat menyebabkan dan memperburuk anemiaa dengan cara menurunkan atau mengurangi produksi eritropoietin atau sensitivitas terhadap hormon ini dan merusak sel progenitor serta hematopoietik yang matur, sementara terapi radiasi menyebabkan kerusakan pada sumsum tulang. ${ }^{7,12}$

- Kehilangan darah dan defisiensi nutrisi merupakan faktor pendukung timbulnya anemiaa pada pasien keganasan anak.

- Metastase ke sumsum tulang dapat menimbulkan kerusakan dan destruksi sel progenitor, menganggu lingkungan mikro dan produksi sel deret eritrosit. ${ }^{12}$

- Adanya gangguan yang diperantarai oleh sitokin (cytokine associated syndrome). Dalam hal ini tumor berinteraksi dengan sistem imun sehingga menyebabkan produksi sitokin yang berlebihan (inflammatory cytokine) seperti interleukin-1, interleukin-6 dan tumor necrosis factor $\alpha$.

Sitokin - sitokin ini dapat mengganggu formasi koloni eritroid dalam merespon eritropoietin, penurunan masa hidup (life span) eritrosit, mengganggu/menghalangi produksi eritropoietin dan mencegah penggunaan besi. ${ }^{7}, 12$

Anemia keganasan adalah normochromic normocytic pada umumnya merupakan anemia ringan $(\mathrm{Hb}>9 \mathrm{~g} /$ $\mathrm{dL}$ ) dan jarang $\mathrm{Hb}<7 \mathrm{~g} / \mathrm{dL}$. Konsentrasi besi serum dan kapasitas ikat besi total (TIBC) menurun, pemeriksaan morfologi sumsum tulang terhadap erythroid precursor tampak normal. ${ }^{12,13}$

\section{Penggunaan Human Erithropoietin Re- combinant (rhu-EPO)}

Pada tahun 1989 FDA (Food and drug administration) menyetujui penggunaan eritropoietin rekombinan pada anemiaa oleh karena gagal ginjal kronik. ${ }^{1,15,16}$ Beberapa peneliti menggunakan eritropoietin rekombinan tersebut sebagai alternatif transfusi pada pasien keganasan, prematuritas, atau penyakit kronik. ${ }^{16}$

Penggunaan eritropoietin pada anak dengan keganasan masih terbatas, terutama studi dilakukan pada pasien dewasa. ${ }^{16}$ Penelitian awal menunjukkan 
penggunaan eritropoietin pada pasien keganasan dengan dosis dan jadwal yang berbeda. Berdasarkan beberapa penelitian tersebut ASCO (American Society of Clinical Oncology) dan ASH (American Society of Hematology) pada 1997 mulai mendiskusikan panduan praktis klinis penggunaan rhu-EPO pada pasien keganasan. Rekomendasi yang dianjurkan sebagai berikut. ${ }^{15}$

1. Pemberian rhu-EPO pada pasien anemia yang disebabkan kemoterapi apabila kadar $\mathrm{Hb} £ 10$ g/ dL. Transfusi sel darah merah pada keadaan anemia berat merupakan pilihan pengobatan.

2. Rhu-EPO digunakan bila kadar $\mathrm{Hb} £ 10 \mathrm{~g} / \mathrm{dL}$ dan tergantung keadaan klinis. Transfusi darah merah dapat merupakan pilihan pengobatan pada keadaan klinis yang berat.

3. Rhu-EPO diberikan secara subkutan 3 kali per minggu dengan dosis awal $150 \mathrm{U} / \mathrm{kg}$ paling sedikit 4 minggu. Dosis dapat ditingkatkan hingga 300 $\mathrm{U} / \mathrm{kg}$ dan dapat diberikan selama $4-8$ minggu; dosis total per minggu $40.000 \mathrm{U}$.

4. Apabila terapi dengan rhu-EPO tidak memberi respons setelah $6-8$ minggu yaitu peningkatan kadar $\mathrm{Hb}$ kurang dari $1-2 \mathrm{~g} / \mathrm{dL}$ dianggap terapi tersebut tidak berhasil dan dipertimbangkan untuk menghentikan pengobatan. Pemeriksaan progresifitas tumor atau kemungkinan defisiensi besi perlu dilakukan.

5. Apabila kadar $\mathrm{Hb}$ telah mendekati $12 \mathrm{~g} / \mathrm{dL}$ maka dosis rhu-EPO harus dikurangi untuk menjaga kestabilan kadar tersebut. Jika kadar Hb turun mendekati 10 terapi awal dapat dimulai kembali.

6. Pemeriksaan secara periodik kadar besi, TIBC, saturasi transferrin, feritin dapat dilakukan untuk membatasi penggunaan rhu-EPO dan mengetahui penyebab gagalnya pengobatan. Waktu pemeriksaan belum dapat ditentukan.

7. Pada beberapa penelitian penggunaan rhu-EPO pada pasien anemiaa yang disebabkan mielodisplasia risiko rendah sangat baik, tetapi belum ada penelitian mendukung penggunaannya pada pasien anemia dengan myeloma, non hodgkin lymphoma atau chronic lymphoblastic leukemia tanpa kemoterapi.

8. Pasien dengan penyakit myeloma, NHL, CLL yang diberikan kemoterapi dengan atau tanpa kortikosteroid, dilakukan observasi hematologis sampai tumor mengalami reduksi sebelum dipertimbangkan pemberian rhu-EPO. Rhu-EPO dapat digunakan bila tidak didapati kenaikan hemoglobin sesudah kemoterapi. Transfusi darah merupakan pilihan pada keadaan klinis yang berat.

Killian A dkk ${ }^{16}$ meneliti secara random, terhadap anak umur $1-7$ tahun dengan diagnosis ALL yang mendapat rhu-EPO $150 \mathrm{U} / \mathrm{kg}$ BB 3x seminggu intravena atau subkutan dibandingkan dengan anak yang tidak mendapatkan rhu-EPO selama tiga periode kemoterapi. Hasil penelitian tidak menunjukkan perbedaan bermakna kebutuhan transfusi. Namun diantara anak-anak yang didiagnosis ALL risiko rendah, secara bermakna lebih sedikit volume transfusi yang diperlukan pada group rhu-EPO dan tidak ditemukan efek samping dengan rhu-EPO, namun defisiensi besi terjadi pada kedua group.

Ludwig Heinz. dkk ${ }^{5}$ melakukan penelitian terhadap 13 pasien dewasa multiple myeloma yang telah mendapat kemoterapi diberikan rhu-EPO dengan dosis awal $150 \mathrm{U} / \mathrm{kg}$ dan diobservasi dalam 3 minggu, dosis dapat dinaikkan hingga $200 \mathrm{U} / \mathrm{kg}$. Periode median pemberian rhu-EPO selama 32 minggu (2 42 minggu). Hasil penelitian sebagai berikut: $85 \%$ terjadi peningkatan $\mathrm{Hb}$ lebih kurang $2 \mathrm{~g} / \mathrm{dL}$ selama 5 minggu dan 2 pasien terjadi peningkatan $\mathrm{Hb}$ lebih dari 2 bulan.

Killian dkk. ${ }^{16}$ melaporkan hasil penelitian secara random dengan menggunakan rhu-EPO dan tanpa rhu-EPO terhadap 34 anak berusia 6 bulan -18 tahun yang menjalani kemoterapi. Dosis rhu-EPO yang diberikan $150 \mathrm{U} / \mathrm{kg} \mathrm{BB}$, 3x seminggu selama 8 minggu terhadap 17 anak sedangkan 17 anak lainnya sebagai kontrol mendapat pengobatan baku. Dijumpai peningkatan rata-rata $\mathrm{Hb}$ dari 8,5 menjadi $10,2 \mathrm{~g} / \mathrm{dL}$ sesudah 4 minggu pengobatan pada group rhu-EPO, pada group kontrol rata-rata $\mathrm{Hb}$ tidak berubah. Secara bermakna lebih sedikit keperluan transfusi pada group rhu-EPO dibanding group kontrol. Satu pasien yang mendapat rhu-EPO mengalami hipertensi dan terapi dihentikan, namun 1 minggu kemudian terapi dilanjutkan tanpa komplikasi lebih lanjut.

Rhu-EPO yang terdapat di pasaran adalah Epoetin - alfa (Epogen, Eprex, Procrit) dan Epoetin-beta (Neorecormon) yang berbeda struktur, proses produksi dan stabilitasnya. Dapat diberikan secara subkutan atau intra-vena, namun pemberian intra-vena memerlukan dosis yang lebih besar dari pada subkutan karena konsentrasinya lebih cepat berkurang dalam serum. ${ }^{16}$ Rhu-EPO berfungsi meningkatkan atau mem- 
pertahankan kadar RBC, sehingga menurunkan keperluan transfusi darah. Masa paruh berkisar antara 4-13 jam pada pasien dengan gagal ginjal kronik setelah intra-melalui vena dan kira-kira 27 jam pada pemberian subkutan. Kadar serum puncak dicapai 524 jam setelah pemberian subkutan. Rhu-EPO merupakan obat yang mahal, sehingga memerlukan biaya lebih dari 1 milyar per tahun. Sediaan rhu-EPO yang tersedia adalah $1000 \mathrm{IU}, 2000 \mathrm{IU}, 4000 \mathrm{U}$ (dalam 1 syringe) $2000 \mathrm{IU}$, dan $4000 \mathrm{IU}$ (dalam 1 ampul). ${ }^{16,17}$ Cheer dan Wagstaff, melaporkan bahwa pemberian epoetin beta sekali seminggu mempunyai efektifitas yang sama dibandingkan pemberian $3 \mathrm{x}$ seminggu pada pasien anemia dengan keganasan hematologi. ${ }^{18}$

\section{Efek Samping dan Kontra Indikasi}

Efek samping yang dilaporkan lebih sering pada pasien dewasa yang menderita gagal ginjal kronik, antara lain hipertensi $(24 \%)$, nyeri kepala (16\%), nyeri tulang (11\%), mual (11\%), edem (9\%), lemah (9\%) dan diare (9\%). Efek samping pada anak yang menderita gagal ginjal hampir sama dengan dewasa. ${ }^{16}$

Ludwig dkk. dalam penelitiannya pada pasien dewasa multiple myeloma menyatakan bahwa tidak terjadi efek samping selama uji klinis. 5 Porter dkk menyatakan efek toksik rhu-EPO minimal, tidak ada pasien yang menderita hipertensi atau kejang, dua pasien mengeluh nyeri pada tempat injeksi, tanpa adanya infeksi. ${ }^{9}$ Studi lain menyatakan pencegahan anemiaa dengan injeksi eritropoietin dua kali per minggu intraperitoneal selama 6 minggu menyebabkan lebih banyak kejadian hipertensi sistemik dan kerusakan glomerular yang ditentukan secara histologis. ${ }^{18}$ Means $\mathrm{dkk}{ }^{20}$ dalam penelitiannya terhadap dua orang pasien yang menerima rhu-EPO selama 8 minggu dengan dosis $150 \mathrm{U} / \mathrm{kg}$, 3x perminggu terjadi defisiensi besi.

Pada pasien gagal ginjal kronik yang mendapat rhuEPO terjadi peningkatan tekanan darah arteri pada beberapa minggu sampai beberapa bulan setelah onset terapi. Umumnya peningkatan tekanan darah berkaitan dengan peningkatan hematokrit pada pasien yang mendapat EPO. Pada beberapa studi terbaru, didapatkan bahwa pada terapi EPO terjadi gangguan sistem vasodilator yang berperan terhadap terjadinya hipertensi. Terapi EPO juga menunjukkan rangsangan pada ekspresi gen renin dan substrat renin kedua ginjal dan jaringan vaskular. Namun beberapa studi menunjukkan bahwa pemberian EPO tidak meningkatkan aktifitas plasma renin atau konsentrasi angiotensin II pada tikus. ${ }^{22}$

Kontra indikasi pemberian epoetin termasuk keadaan hipertensi yang tidak terkontrol, hipersensitif terhadap albumin yang berasal dari mamalia atau manusia, pada pasien gagal ginjal kronik dengan anemiaa berat, atau pada pasien HIV maupun keganasan yang mengalami anemiaa yang disebabkan oleh defisiensi besi, folat, hemolisis, atau perdarahan cerna. ${ }^{17}$ Meskipun tidak ada obat yang berinteraksi bermakna dengan epoetin, namun beberapa peneliti melaporkan diperlukan dosis yang lebih besar pada pasien yang mendapat angiotensin converting enzim inhibitor dan yang mendapat heparin. ${ }^{16}$

\section{Kesimpulan}

Rhu-EPO bermanfaat mengurangi kebutuhan transfusi darah pada pasien anak dengan keganasan, dengan efek samping yang minimal. Beberapa kasus dilaporkan terjadinya aplasia sel darah merah oleh karena penggunaan epoetin alfa khususnya Eprex. Diperlukan monitoring secara periodik pada penggunaan epoetin.

\section{Daftar Pustaka}

1. The agency for health care research and quality (AHRQ). Uses of epoetin for anemiaa in oncology. Evidence report/technology assessment 2001; 30:1-13.

2. Christensen RD, Ohls RK,. Development of the hematopoieric system. Dalam: Behrman RE, Kliegman RM, Arvin Am, penyunting. Nelson textbook of pediatrics. Edisi ke-15. Philadelphia: Saunders, 1996. h. 1375-82.

3. Firat D, Banzon J. Erythropoietic effect of plasma from patients with advanced cancer. Cancer Res 1971; 31:1353-9.

4. Brumariu O, Miron I, Munteanu M, Gavrilovici C. The use of growth factors in pediatric diseases. Didapat dari: URL: http://www.nefroped.net 2000.rolarticle 002. htm

5. Ludwig H. Eritz E, Kotzmann H, Hocker P, Gisslinger H, Barnas U. Erythropoetin treatment of anemiaa associated with multiple myeloma. N Engl J Med 1990; 322:1693-9. 
6. Lubis B. Eritropoietin pada sepsis pediatrik. Disampaikan pada Simposium Nasional Pediatri Gawat Darurat VI, Medan, 4 Oktober, 2003.

7. Miller DR. Eritropoietin, hypoplastic anemiaas, and disorders of heme synthesis, Dalam: Miller DR, Bachner RL, Miller LP. Blood diseases of infancy and childhood. Edisi ke - 7. St Louis: Mosby, 1995. h. 140-82.

8. Ganong WF. Erythropoetin. Riview of Medical Physiology. Edisi ke 14. London: Prentice - Hall, 1989. h. 392.

9. Porter JC, Leahey A, Polise K, Buning, Manno CS. Recombinant human erythropoietin reduces the need erythrocyte and platelet transfusion in pediatrics patient with sarcoma: A randomized, double-blind, placebocontrolled trial. J Pediatr, 1996; 129:656-60.

10. Miller CB, Platanias LC, Mills SR, Zahurak ML, Ratain MJ, Ettinger DS. Phase I - II trial of erythropoetin in the treatment of cisplatin - associated anemiaa. J National Cancer Institute 1992; 84:100-3

11. Dainiak N, Kulkarni V, Howard D, Kalmanti M, Dewey MC, Hoffman R. Mechanism of abnormal erythropoiesis in malignancy. Cancer, 1983; 51:1101-6.

12. Permono B. Anemiaa dan eritropoitin. Disampaikan pada Simposium Nasional Nefrologi Anak IX HematoOnkologi Anak. Batu. 12-14 Desember, 2003.

13. Miller CB, Jones RJ, Piantodosi S, Abeloff MD, Spivak JL. Decreased erythropoietin response in patients with the anemiaa of cancer. N Engl J Med 1990; 322:1689-2.

14. Pizzo PA, Poplack DG. Erythrocyte replacement therapy.
Principles and practice of pediatric oncology. Edisi ke3. Philadelphia: Lippincott-Raven, 1997. h. 1053.

15. Rizzo JD, Lichtin AE, Woold SH, Seldenfeld J, Bennett CL, Cella D, et al. Use of epoetin in patients with cancers ; evidence - based clinical practice guidelines of the American Society of Clinical Oncology and the American Society of Hematology. Blood 2002; 100:2303-20.

16. Killian A. Pediatric use of recombinat human erythropoetin. Pediatr Pharm 2002; 8:1-5.

17. Drug information organized alphabetically. Epoetin alfa recombinant. Diambil dari: URL : http://www. healhdigest.or/ duglepoetinalfarecombinant.html.

18. Cheer SM, Wagstaff AJ. Epoetin beta: a review of its clinical use in the treatment of anemiaa in patients with cancer. Drugs 2004; 64 (3):323-46.

19. Exchbach JW, Kelly MR, Haley R. Treatment of the anemiaa of progressive renal failure with recombinant human erythropoetin. N. Engl J Med 1989; 321:15863.

20. Means RT. Olsen NJ, Krantz SB.Treatment of the anemiaa of rheumatoid arthritis with recombinant human erythropoetin: Clinical and in vitro studies. Arthitis and rheumatoid, 1989; 32:638-42.

21. Cazzola M. Erythropoietin therapy : need for rationality and active survaillance. Heamatologica 2003; 06:601-3

22. Vaziri ND, Tang DH, Dissociation of the pressor and erythropoetic effects of Erythropoetin. Didapat dari URL: http:/www.uninet.edu/cid2000/ comferences/ vaziri.html. 